\section{Royal Institution}

Ax the anyiversary meeting of the members of the Royal Institution held on May 2, the following officers were elected: President : Lord Brabazon of Tara Secretary : Prof. A. O. Rankine ; Treasurer: Dr. R. E. Slade; Managers: Prof. D. Brunt, Major W. H. Cadman, Sir John Craig, Mr. E. R. Davies, Dr. C. H. Desch, Prof. H. Dingle, Dr. P. Dunsheath, Prof. G. I. Finch, Prof. F. L. Hopwood, Dr. E. T. Paris, Prof. H. J. Plenderleith, Sir wHarry Railing, Prof. H. R. Robinson, Prof. A. M. Tyndall, Mr. F. Wakeham; Visitors : Colonel S. J.M. Auld, Dr. H. E. Cox, Dr. H. J. T. Ellingham, Dr. R. E. Gibbs, Prof. H. Heywood, Mr. A. J. Hughes, Dr. L. H. Lampitt, Mr. R. Le Rossignol, Mr. A. Marshall, Dr. D. C. Martin, Dr. A. C. G. Menzies, Mr. J. W. Ryde, Mr. F. M. Saxelby, Dr. H. Shaw, Dr. O. H. WansbroughJones.

\section{Capper Pass Awards for Metallurgy}

THE Capper Pass Awards for 1948, which are recommended by a committee on behalf of the Institution of Mining and Metallurgy and of the Institute of Metals, have been won by the following : Miessrs. C/Blazey, L. Broad, W. S. Gummer and D. P. Thompson (Metal Manufacturers, Ltd., Port Kembla, New South Wales, Australia) £50 jointly, for a paper on "The Flow of Metal in Tube Extrusigh" ; Mr. H. R. Potts (Minas de Rio Tinto) £50, for a paper on "Further Notes on Converter Practice at Rio Tinto"; Messrs. R. C. Trumbull (Pyrites Co., Inc.), W. Hardiek (Pyrites Co., Inc.) and E. G. Lawford (Rio Tinto Co., Ltd.) $£ 50$ jointly, for a paper on "Notes on the Treatment of Pyrites Cinders at the Plant of the Pyrites Co., Inc., Wilmington, Delaware". The money for these awards has been given by Messrs. Capper Pass and Son, Ltd., Bristol, and is allotted as follows: $£ 100$ each year for one or more awards to authors of papers on some aspect of non-ferrous extraction metallurgy submitted to the Institution of Mining and Metallurgy ; and $£ 100$ each year for one or more awards to authors of papers submitted to the Institute of Metals and relating to some process or plant used in the fabrication of non-ferrous metals, contributed by persons engaged full-time in industrial practice. All papers relating to these fields and published in 1949 by either of the two Societies will be considered for awards; authors need not be members of either Society and may be resident in any country. Manuscripts should preferably be submitted in duplicate to either the Secretary, Institution of Mining and Metallurgy, Salisbury House, Finsbury Circus, London, E.C.2, or the Secretary, Institute of Metals, 4 Grosvenor Gardens, London, S.W.1, from whom further particulars may be obtained.

\section{Royal Aeronautical Society: Awards}

THE Royal Aeronautical Society has announced the awged of the following medals and prizes: British/Gold Medal, for practical achievement in aerondutics, to Mr. S. Camm, director and chief desifner, Hawker Aircraft, Ltd., for his outstanding whrk in the design and development of fighter airraft ; British Silver Medal, for practical achievement in aeronautics, to Lieut.-Commander E. M. Brown, for his outstanding achievements in advancing the technique of deck landing; Royal Aeronautical Society's Bronze Medal to Capt. R. N. Liptrot, for his work on helicopters; Wakefield Gotd Medal to
Mr. E. S. Calvert, for his work in the development of airport lighting; George Taylor (of Australia) Gold Medal to Mr. G. R. Edwards, chief designer, Vickers Armstrongs, Ltd., Weybridge Works, for his paper on "Problems in the Development of a New Aero. plane" ; Edward Busk Memorial Prize to Mir. W. Stewart, for his paper on the "Flight Testing of Helicopters"; Herbert Ackroyd Stuart Memorial Prize to Mr. W. H. Lindsey, for his paper on "De. velopment of the Armstrong Siddeley Mamba Engine" ; Usborne Prize to Mr. D. R. Maguire, for his paper on "Enemy Jet History"; $R$. P. Alston Memorial Prize to Mr. B. A. G. Megowan, for his work in the flight testing of gliders; Baden-Powell Memorial Prize to Mr. R. J. Starling, for being the best entrant in the associate fellowship examination.

\section{Announcements}

Dr. JонN RAMsвотTом, keeper of botany in the British Mhuseum (Natural History), has been awarded a Grande Médaille Isidore Geoffroy Sainte-Hilaire by thy Société d'Acclimatation et de Protection de la Xature.

THE Institute of Metals has appointed the following to be honerary corresponding members for their respectiy countries : Belgium, Henri Féron, admin. istratifo director, Visseries et Tréfileries Réunis S.A., Haren; Holland, Max Hamburger, director, Royal Nederlandsche Lood- en Zinkpletterijen voorheen A.D. Hamburger, Utrecht; Italy, Dr. Leno Matteoli, vice-director, Istituto Scientifico Tecnico Ernesto Breda, Sesto S. Giovanni, Milan.

THE Assgeiation of Universities of the British Commonyealth, 5 Gordon Square, London, W.C.1, has published as a booklet of sixty pages Appendix III from the "Universities Yearbook" of 1948. This Appendix consists of a list of postgraduate scholarKips and grants for advanced study and research ten able at the universities of Great Britain and Ireland during 1948-49, and though the awards for 1949 have for the most part been already made, yet most of the information will be applicable to next year. The classification of contents is by subjects.

THE Italian review Ulisse is offering a prize of one million lire (about 1450 ) for the best work of popular science in the fields of physics or chemistry which hag been published in the last five years. The prize ifopen to books published in Italian, French, English, Spanish and German, and three copies of each book entered for the prize should be sent to Revista Ulisse (Sezione Premio Europeo Cortina), Corso d'Italia 43, Rome, before June 15. If the winning work is by a non-Italian author, it is hoped to arrange for the book to be translated into Italian and published in Italy.

REFERENCE was made in Nature of April 23, p. 618, to the stting up, by the Parliamentary and Scientific Com/nittee, of a sub-committee to investigate the question of payment for scientific and medical teaching staffs at the universities. We are informed that in view of the new circumstances it has been decided not to proceed with this matter.

Errayum.-In the announcement in Nature of April 23, p. 634, relating to the Busk aeronautical stydentship, it should have been indicated that, subject to the permission of the trustees, the student may carry out his research in Great Britain or abroad. 